\title{
Physicochemical and sensory characterization of gluten-free fresh pasta with addition of passion fruit peel flour
}

\author{
Taís Helena Santos Ribeiro ${ }^{1}$ - Beatriz Cervejeira Bolanho ${ }^{1}$ \\ Flávia Daiana Montanuci ${ }^{1}$ S Suelen Pereira Ruiz ${ }^{{ }^{*}}$
} ${ }^{1}$ Departamento de Tecnologia, Universidade Estadual de Maringá (UEM), 87506-370, Umuarama, PR, Brasil. E-mail: suelen.ruiz@gmail.com.
${ }^{*}$ Corresponding author.

\begin{abstract}
The aim of this study was to develop a gluten-free fresh pasta formulation with addition of yellow passion fruit peel flour $(P P F)$. A control formulation containing a mixture of rice flour and corn flour and formulations with 10 and $20 \%$ of PPF addition were produced. Sensory analysis, physicochemical characterization and technological properties were assessed. The PPF addition to gluten-free pasta increased cooking time, soluble solids loss and water absorption; it also modified the color of the formulations. The control formulation and the formulation containing $10 \%$ PPF had the best sensory parameters, leading to an acceptability index over $70 \%$. The $10 \%$ PPF addition increased fiber $(3.25 \%)$ and ashes $(2.15 \%)$ content and also lowered percentage of carbohydrates $(41.19 \%)$ and energy value $(223.26 \mathrm{kcal} / 80 \mathrm{~g})$; content of proteins and lipids were similar between the formulations. Principal component analysis showed that the control formulation stands out due to its sensory properties while the formulation containing $10 \%$ PPF improved nutritional properties. Therefore, the increase in nutritional value of gluten-free fresh pasta due to the PPF addition can be considered an alternative to meet market demands for healthier food choices.
\end{abstract}

Key words: maize flour, rice flour, byproduct, Passiflora edulis.

Características físico-químicas e sensoriais de massa alimentícia fresca sem glúten com adição de farinha de casca de maracujá

RESUMO: O objetivo deste estudo foi desenvolver massa alimentícia fresca sem glúten com adição de farinha de casca de maracujá amarelo (FCM). Uma formulação controle composta de uma mistura de farinha de arroz e farinha de milho, e formulações com adição de 10 e $20 \%$ de FCM foram produzidas. As amostras foram analisadas quanto às características sensoriais, fisico-químicas e tecnológicas. A adição de FCM às formulações aumentou o tempo de cozimento, a perda de sólidos solúveis e a absorção de água, bem como, modificou os parâmetros de cor. As formulações que apresentaram melhores resultados, quanto aos atributos sensoriais, foram o controle e a que continha $10 \%$ de adição de FCM, que apresentaram indice de aceitabilidade acima de 70\%. A adição de 10\% de FCM aumentou o teor de fibras (3,25\%) e cinzas $(2,15 \%)$ e reduziu a porcentagem de carboidratos $(41,19 \%)$ e o valor energético $(223,26 \mathrm{kcal} / 80 \mathrm{~g})$, enquanto o teor de proteinas e lipídios foi semelhante entre formulações. A análise de componentes principais demonstrou que a amostra controle se destacou por suas propriedades sensoriais, enquanto a adição de $10 \%$ de FCM promoveu as propriedades nutricionais. Portanto, o aumento do valor nutricional da massa fresca sem glúten produzida com adição de FCM pode ser considerada uma alternativa para atender uma demanda crescente do mercado que busca escolhas alimentares mais saudáveis.

Palavras-chave: farinha de milho, farinha de arroz, subproduto, Passiflora edulis.

\section{INTRODUCTION}

Passion fruit belongs to Passifloraceae family, and the Passiflora genus contains approximately 500 species. This fruit is of great economic importance for Brazil, which is responsible for approximately $60 \%$ of its worldwide production. Yellow passion fruit (Passiflora edulis f. flavicarpa) has attractive flavor and aroma; its consumption happens in natura and its derivatives are consumed as concentrated juice (MANIWARA et al., 2014; CORRÊA et al., 2016). Processing of this fruit at industrial scale leaves a considerable amount of fruit peels as by-products (PINHEIRO et al., 2008). The passion fruit peel amounts to $60 \%$ (in mass) of the whole fruit and it is composed of flavedo 
and albedo. The flavedo contains large amounts of bioactive compounds, such as the flavonoid luteolin and fibers, which have the ability to reduce LDL and increase HDL levels, useful for improving treatment of diseases such as diabetes and promoting reduction of body weight. The albedo contains a high content of niacin, iron, calcium, and pectin, which has wide use in the food industry as a gelling agent, stabilizer and thickener (OLIVEIRA et al., 2016a; LÓPEZVARGAS et al., 2013).

Celiac disease is an immune-mediated enteropathy which develops in genetically susceptible individuals, and it is caused due to the ingestion of gluten proteins reported in cereals, such as wheat, barley, rye and certain oats varieties. This disease leads to immune-based damage caused on the small intestine and can also aggravate other diseases, such as osteoporosis, and due to its prevalence, is considered a concern for public health agencies (SANGUINETTI et al., 2016; SOLER et al., 2016). Treatment of this disease requires exclusion of gluten from the diet, which ensures proper physiological development of the organism, maintaining the homeostasis of bone mineral density and fertility and reducing the risk of nutritional deficiencies (MORENO et al., 2016). In order to meet market demand for better glutenfree products, development of gluten-free foods and beverages has acquired great importance in recent years (SHARMA et al., 2015).

Brazil has the third largest consumer market of pasta in the world; in 2015 its consumption was of around 1.24 million tons (ABIMAPI, 2016). Pasta is the resulting product of mechanical kneading (with no post-fermentation) of wheat flour and/or durum wheat products and/or other cereals, legumes, roots and tuber products (BRASIL, 2005). Glutenfree cereal flours can be used in food processing as a substitute for wheat flour. Maize flour is a low-cost raw material which contains approximately $10 \%$ of proteins and natural pigments, such as cryptoxanthin and zeaxanthin, which are vitamin A precursors and also act as natural dyes conferring pigmentation to foods products (NUSS \& TANUMIHARDJO, 2010). The use of rice flour derived from broken grains which would be discarded due to not meeting quality standards adds value to rice production chains by preventing waste generation. The addition of rice flour to a food formulation is interesting due to the low sodium levels and good digestibility (ASMEDA et al., 2016; PHONGTHAI, et al., 2017).

New technologies aimed to improve the use of gluten-free flours and agro industrial by-products have been studied. When used in the development of a food product, these ingredients can improve nutritional parameters of such product due to their high contents of fiber, vitamins and minerals; however, they should not adversely affect sensory and technological properties of the formulated product (LIAO \& HUNG, 2015). The aim of this research was to develop and characterize formulations of gluten-free fresh pasta containing passion fruit peel flour.

\section{MATERIALS AND METHODS}

Passion fruit peel flour (PPF), rice flour and corn flour were obtained from the local market in the city of Umuarama/PR/Brazil. All reagents used were of analytical grade. Three formulations of fresh pasta were developed, as shown in table 1. The control formulation was produced with maize and rice flours only, and other two formulations were produced by adding PPF to final concentrations of $10 \%$ and $20 \%$ replacing maize and rice flours. These percentages of PPF were defined in preliminary tests. The pasta formulations were processed manually and molded to fettuccine format using a pasta extruder (GPANIZ MF5, Brazil).

Technological properties (cooking time, water adsorption, soluble solids loss and volume increase) of the pasta formulations produced were evaluated according to methods 66-50.01 of AACC (1999). Cooking time was determined by cooking $10 \mathrm{~g}$ of sample pasta in $140 \mathrm{~mL}$ of boiling distilled water; the cooked product was pressed every 30 seconds against two glass slides, until gelatinization of starch granules (disappearance of intact starch granules). Results were expressed in minutes.

Table 1 - Formulations of gluten-free fresh pasta.

\begin{tabular}{lccc|}
\hline Ingredients & Control & $\begin{array}{c}10 \% \\
\text { PPF }\end{array}$ & $\begin{array}{c}20 \% \\
\text { PPF }\end{array}$ \\
\hline Rice flour $(\mathrm{g})$ & 70 & 65 & 60 \\
Maize flour $(\mathrm{g})$ & 30 & 25 & 20 \\
\hline Yellow passion fruit peel flour $(\mathrm{g})$ & 0 & 10 & 20 \\
Water $(\mathrm{mL})$ & 50 & 50 & 50 \\
\hline Salt $(\mathrm{g})$ & 1 & 1 & 1 \\
Oil $(\mathrm{mL})$ & 6 & 6 & 6 \\
Xanthan gum $(\mathrm{g})$ & 1 & 1 & 1 \\
\hline Egg $(\mathrm{g})$ & 50 & 50 & 50 \\
\hline
\end{tabular}

Note: Control - without passion fruit peel flour; PPF - passion fruit peel flour. 
Water absorption was determined according to FOGAGNOLI \& SERAVALLI (2014), by assessing the pasta weight increase during cooking. Samples $(100 \mathrm{~g})$ were weighed before and after cooking, and a ratio between these values generated the final results. After cooking, the remaining water used was placed under $105^{\circ} \mathrm{C}$ until constant weight would be reached in order to determine the soluble solids loss. The volume increase was determined by assessing the water volume displaced by $10 \mathrm{~g}$ of pasta both before and after cooking. Results were expressed as percentages (AACC, 1999).

Color parameters of pasta formulations were assessed using a digital colorimeter (KONICA MINOLTA Chroma Meter, CR-400, Japan); the parameters luminosity $\left(\mathrm{L}^{*}\right)$, chromaticity - intensity of red/green $\left(a^{*}\right)$ and intensity of yellow/blue $\left(b^{*}\right)$, according to the CIE (International Commission on Illumination) model (MCGUIRE, 1992), were assessed.

Sensory analysis of the pasta formulations were carried out by applying an acceptance test to a group of untrained testers $(n=101)$ composed of individuals of both sexes and ages ranging from 16 to 60 years. A structured nine-point hedonic scale was used $(9=$ like extremely; $8=$ like very much; $7=$ like moderately; $6=$ like slightly; $5=$ neither like nor dislike; 4 = dislike slightly; 3 = dislike moderately; 2 = dislike very much; 1 = dislike extremely) and the attributes overall appearance, taste, flavor, texture and color were evaluated. The sensory analysis procedure was approved by the Ethics Committee - COPEP-UEM/ CAAE: 54973116.1.0000.0104. Portions of 200g of pasta were cooked in $2.8 \mathrm{~L}$ of water and $1 \mathrm{~g}$ of salt at the time point defined previously by the cooking test. Cooked samples $(20 \mathrm{~g})$ were provided to the testers in encoded disposable cups at random. The acceptability index (AI) of the formulations was calculated according to Equation 1, where $\mathrm{A}$ is the average grade obtained for the tested sample and B is the maximum grade given to the same sample (DUTCOSKY, 2013).

$$
I A(\%)=\frac{A x 100}{B}
$$

The pasta formulations which obtained the best results from the sensory analysis underwent further analyses. Moisture, ashes, protein, lipid and fiber content according to the AOAC (1995) (total carbohydrates estimated by difference) were evaluated. The energy value was calculated using the conversion factors established by the resolution RDC $n^{\circ} 360$ of December 23, 2003 (BRASIL, 2003a) and it was expressed in $\mathrm{kcal} / 80 \mathrm{~g}$ of pasta as recommended by resolution RDC No 359 of December 23, 2003 (BRASIL, 2003b), and compared with control pasta.
All assays were carried out in triplicates. In order to analyze the results, Student t-tests and one way analysis of variance (ANOVA) followed by Tukey posthoc tests were carried out for assessment of two or three or more groups, respectively. Statistical differences were considered significant assuming $p<0.05$. All analyses were carried out with the aid of Statistica ${ }^{\circledR} 8.0$ software. The same software was also used to carry out Principal Component Analysis (PCA).

\section{RESULTS AND DISCUSSION}

Regarding results for technological properties (Table 2), cooking times of the pastas containing $10 \%$ PPF and $20 \%$ PPF were similar ( $p>0.05$ ), but they differed from the time determined for control sample, which can be attributed to the increase in fiber content of the formulations containing PPF (GATTA et al., 2017). The values reported in the present research were similar to the results observed by GATTA et al. (2017) (9min for spaghetti produced with semolina and $20 \%$ of wheat bran), but lower than those reported by FERREIRA et al. (2016) (11 $15 \mathrm{~min}$ for gluten-free pasta developed with a mixture of sorghum-rice-corn flour and potato starch). Thus, the type of flours used for pasta production can influence its cooking time.

Pastas prepared with PPF absorbed more water in comparison to control sample not containing PPF. Such effect might be due to the high fiber content of the PPF (30.11\%) added to the pasta formulation, as fiber components possess plenty of polar groups which can retain water (DHARMARAJ et al., 2016). LORUSSO et al. (2017) reported a value of $128.6 \%$ of water absorption for pasta prepared with semolina flour, which was lower than the values reported in the present study, evidencing that the use of gluten-free flours can also contribute to water absorption.

FOGAGNOLI \& SERAVALLI (2014) state that higher amounts of gluten-free flour used for preparation of pasta can affect the volume increase during cooking, which also depends on cooking time, pasta format and content and quality of gluten proteins. In the present research, addition of PPF to the pasta formulations here tested did not influence this parameter.

The soluble solids loss was higher in formulations containing PPF than in the control formulation; values for loss of soluble solids up to $6 \%$ are considered adequate for pastas to be classified as of high quality, according to HUMMEL (1966). AJILA et al. (2010) stated that loss of soluble solids is an important parameter for evaluation of overall 
Table 2 - Technological properties of gluten-free fresh pasta formulations.

\begin{tabular}{lcccc}
\hline Formulation & Cooking time (min) & Water absorption (\%) & Volume increase (\%) & Soluble solids loss (\%) \\
\hline Control & $9: 53^{\mathrm{b}} \pm 5.66$ & $200.18^{\mathrm{c}} \pm 0.98$ & $1.05^{\mathrm{a}} \pm 0.07$ & $0.05^{\mathrm{b}} \pm 0.00$ \\
$10 \%$ PPF & $10: 05^{\mathrm{a}} \pm 7.07$ & $236.92^{\mathrm{b}} \pm 3.41$ & $1.03^{\mathrm{a}} \pm 0.04$ & $0.11^{\mathrm{a}} \pm 0.01$ \\
$20 \%$ PPF & $10: 36^{\mathrm{a}} \pm 1.41$ & $265.15^{\mathrm{a}} \pm 0.40$ & $1.03^{\mathrm{a}} \pm 0.04$ & $0.10^{\mathrm{a}} \pm 0.02$ \\
\hline
\end{tabular}

Note: Control - without passion fruit peel flour; $10 \%$ PPF - formulation with $10 \%$ of passion fruit peel flour; $20 \%$ PPF - formulation with $20 \%$ of passion fruit peel flour. The averages of the columns followed by the same letter do not differ from each other, by the Tukey test at $5 \%$ probability.

quality of pasta. During the cooking process, some of the starch and other soluble components dissolve in water causing it to become cloudy and thick as result.

Color is one of the parameters that best define product quality and consumer acceptance. As expected, addition of PPF changed the color of the formulations as shown in figure 1. The color parameters assessed (Table 3 ) showed that the control formulation had the highest luminosity $\left(\mathrm{L}^{*}\right)$, which is due to no addition of PPF. The PPF addition to the pasta decreased luminosity values and modified the $\mathrm{a}^{*}$ and $b^{*}$ chromaticity values. MICELI et al. (2015) also noted a color modification in fresh pasta produced with addition of borage leaves. According to these authors, colored pasta has achieved market success in recent years and is well accepted by consumers.

Results of the sensory analysis of the pasta formulations (Figure 2) showed that for attributes overall appearance, taste and color, the control formulation had the highest acceptance among testers, followed by the pastas developed with $10 \%$ and $20 \%$ PPF addition. The values for flavor and

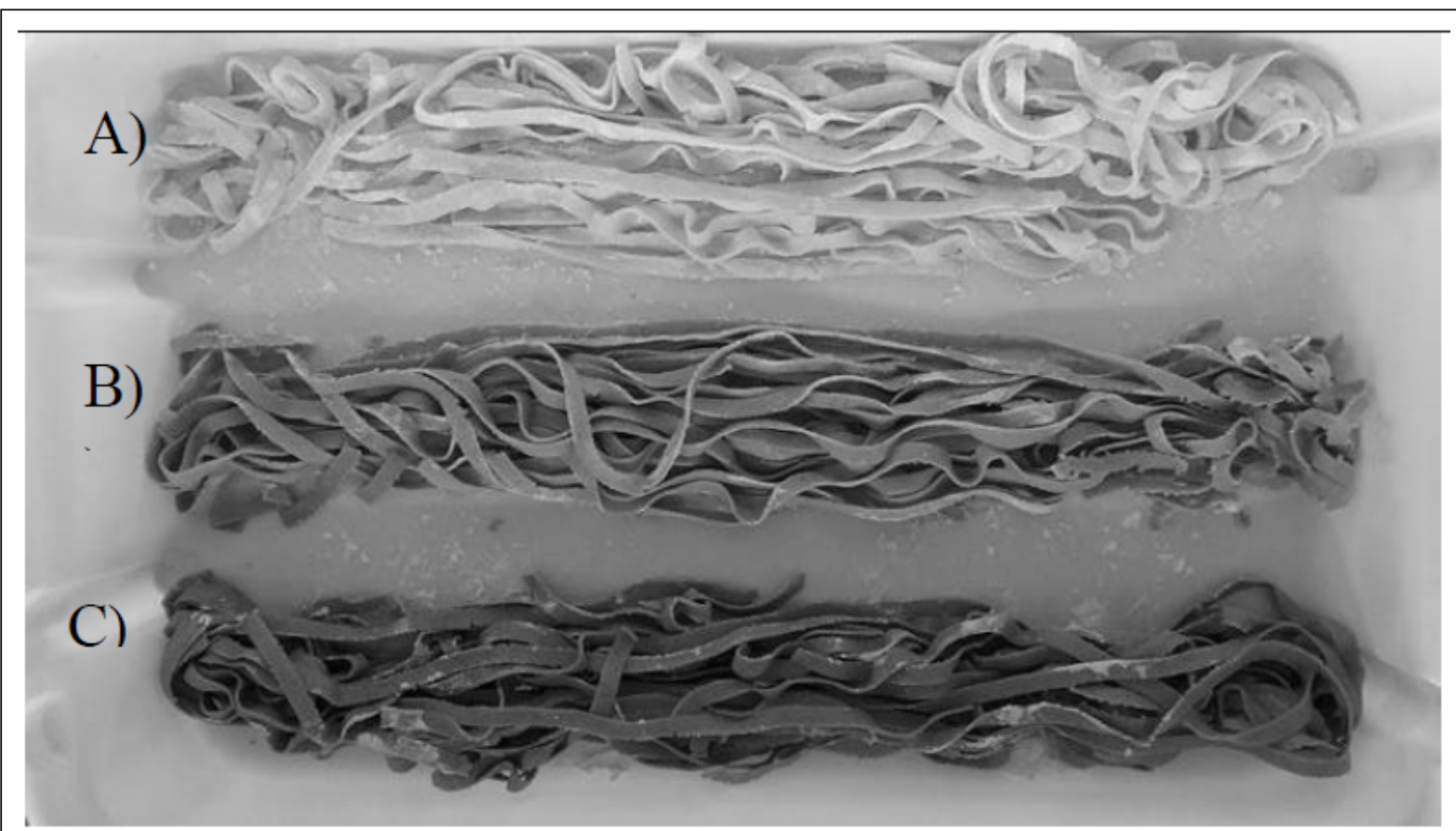

Figure 1 - Gluten-free fresh pasta with passion fruit peel addition (PPF). (A). control, (B). 10\% PPF addition and (C). 20\% PPF addition. 
Table 3 - Color parameters $\left(\mathrm{L}, \mathrm{a}^{*}, \mathrm{~b}^{*}\right)$ of the gluten-free fresh pasta formulations.

\begin{tabular}{lcrr}
\hline Formulation & $\mathrm{L}$ & $\mathrm{a}^{*}$ & $\mathrm{~b}^{*}$ \\
\hline Control & $79.47^{\mathrm{a}} \pm 0.37$ & $-0.24^{\mathrm{c}} \pm 0.06$ & $22.66^{\mathrm{b}} \pm 0.84$ \\
$10 \%$ PPF & $63.38^{\mathrm{b}} \pm 2.64$ & $3.28^{\mathrm{b}} \pm 0.19$ & $25.57^{\mathrm{a}} \pm 2.39$ \\
$20 \%$ PPF & $58.45^{\mathrm{c}} \pm 1.10$ & $4.05^{\mathrm{a}} \pm 0.07$ & $20.08^{\mathrm{c}} \pm 1.16$ \\
\hline
\end{tabular}

Note: Control - without passion fruit peel flour; $10 \%$ PPF - formulation with $10 \%$ of passion fruit peel flour; $20 \%$ PPF - formulation with $20 \%$ of passion fruit peel flour. The averages of the columns followed by the same letter do not differ from each other, by the Tukey test at $5 \%$ probability.

texture did not differ between the control formulation and the formulations containing $10 \%$ PPF $(\mathrm{p}>0.05)$, but these values were higher in comparison to the values for pasta with $20 \%$ PPF addition $(\mathrm{p}<0.05)$. COSTA et al. (2015) developed pasta formulations with wheat flour and passion fruit peel flour, and the control formulation also had greater acceptance among testers, followed by formulations with lower amounts $(25 \%)$ of passion fruit peel flour, results similar to those reported in the present study.

The acceptability index for overall appearance was 80.97, 70.74 and $54.13 \%$ for the control formulation and for the formulations containing 10\% PPF and 20\% PPF, respectively. An acceptability index of at least $70 \%$ is required for a product to have its sensory properties considered as

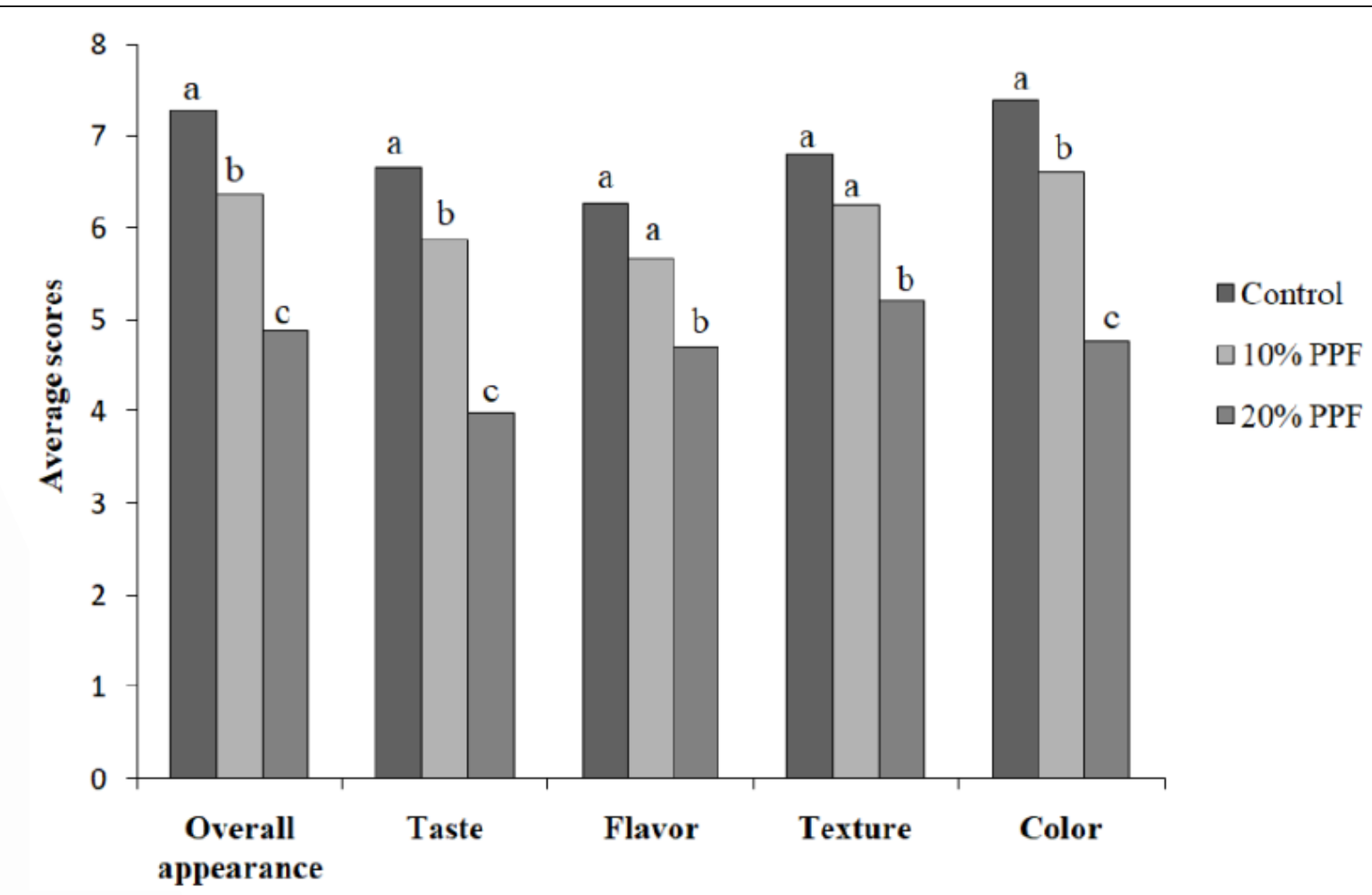

Figure 2 - Average scores obtained by the sensory evaluation of gluten-free fresh pasta formulations. Note: Control - without passion fruit peel flour; $10 \%$ PPF - formulation with $10 \%$ of passion fruit peel flour; $20 \%$ PPF - formulation with $20 \%$ of passion fruit peel flour. 
accepted (TEIXEIRA et al., 1987). BOUASLA et al. (2017) also evaluated the properties of gluten-free precooked rice pasta enriched with different amounts $(10 \%, 20 \%$ and $30 \%)$ of legume flours (yellow pea, chickpea and lentil), and all formulations had acceptable scores for appearance, stickiness, color, flavor and taste. YING (2016) verified the acceptance of pasta developed with addition of purple passion fruit wheat flour and reported an overall acceptance among testers of $64.68 \%$.

Sensory acceptance analysis also provided data regarding purchasing intention; 48.44, 35.94 and $15.62 \%$ of the testers would purchase the control formulation and the formulations containing $10 \% \mathrm{PPF}$ and $20 \% \mathrm{PPF}$, respectively, indicating that the less PPF added to the formulation, the better acceptability of the gluten-free pasta becomes.

The formulation developed with $10 \%$ PPF addition had better technological and sensory properties than the pasta formulation containing $20 \%$ PPF. Thus, the proximal compositions of the control formulation and the formulation containing 10\% PPF were assessed; results are shown in table 4. Regarding moisture content, resolution RDC $\mathrm{n}^{\circ} 93$ of October 31, 2000 (BRASIL, 2000) establish that the maximum value for wet or fresh pasta should be $35 \%$; therefore, the results for this parameter obtained in the present study indicated the formulations assessed are in accordance with Brazilian legislation. In the present study, there was a significant difference in the moisture contents between the control and the formulation containing $10 \%$ PPF. According to OLIVEIRA et al. (2016b) the presence of fibers in yellow passion fruit flour contributed to water retention, increasing the moisture content of food products.

Protein content of the formulations did not differ among them $(p>0.05)$, and the values were similar to those reported by OVANDO-MARTINÉZ et al. (2009) in their study on spaghetti with addition of $45 \%$ green banana flour. AJILA et al. (2010); however, reported obtaining a lower protein content (3.6\%) in pasta formulations enriched with mango by-products in comparison to the values obtained in the present research. Lipid contents of the control and the $10 \%$ PPF formulation were similar, but the values were higher than the ones reported by FERREIRA et al. (2016) in pasta produced with different types of flours. Ashes content was higher in the formulation enriched with PPF in comparison to the control pasta. Minerals have important roles in human physiology as constituents of body tissues, regulators of metabolism of various enzymes and keeping acid-base balance. The deficiency of one or more mineral components can lead to major organic disorders, such as osteoporosis and anemia (SOETAN, et al. 2010). Addition of 10\% PPF to pasta formulation increased fiber content in comparison to the control. According to resolution RDC 54 of November 12, 2012 (BRASIL, 2012), for a food product to be considered a source of fiber it must have $2.5 \mathrm{~g}$ of fibers per portion of food. As the formulation containing $10 \%$ PPF had $2.6 \mathrm{~g}$ of fiber per portion, it can be considered a source of fiber. Presence of fibers contributed to satiety after food consumption and it can help to lower the glycemic index (COSTA et al., 2015; OLIVEIRA et al., 2016b).

The energy value of the control formulation was $249.86 \mathrm{kcal} / 80 \mathrm{~g}$, higher than the value obtained for the formulation containing $10 \%$ PPF $(223.26 \mathrm{kcal} / 80 \mathrm{~g})$, which is due to replacement of cereal flours by passion fruit peel flour.

Analysis of the results was carried out using the principal component analysis (PCA), shown in figure 3 , which demonstrates the projection of the assessed parameters (Figure 3A) and the formulations (Figure 3B) on factorial planes (PC1xPC2). The two principal components (PC) were responsible for $98.64 \%$ of the total variance. REKAS \& LUKASIAK (2015), in pasta developed

Table 4 - Proximal composition of the gluten-free fresh pasta formulations.

\begin{tabular}{lcccccc}
\hline Formula-tion & Moisture (\%) & Protein (\%) & Lipids (\%) & Ashes (\%) & Fiber (\%) & TC (\%) \\
\hline Control & $31.31^{\mathrm{b}} \pm 0.75$ & $8.77^{\mathrm{a}} \pm 0.88$ & $8.68^{\mathrm{a}} \pm 0.60$ & $0.87^{\mathrm{b}} \pm 0.18$ & $1.18^{\mathrm{b}} \pm 0.56$ & $49.19^{\mathrm{a}} \pm 1.92$ \\
$10 \%$ PPF & $34.32^{\mathrm{a}} \pm 0.38$ & $7.40^{\mathrm{a}} \pm 0.20$ & $8.69^{\mathrm{a}} \pm 0.02$ & $2.15^{\mathrm{a}} \pm 0.16$ & $3.25^{\mathrm{a}} \pm 0.16$ & $41.19^{\mathrm{b}} \pm 0.38$ \\
\hline
\end{tabular}

Note: Control - without passion fruit peel flour; $10 \%$ PPF - formulation with $10 \%$ of passion fruit peel flour; $20 \%$ of PPF - formulation with $20 \%$ of passion fruit peel flour; TC - total carbohydrates. The averages of the columns followed by the same letter do not differ from each other, by the test-T at $5 \%$ probability. 


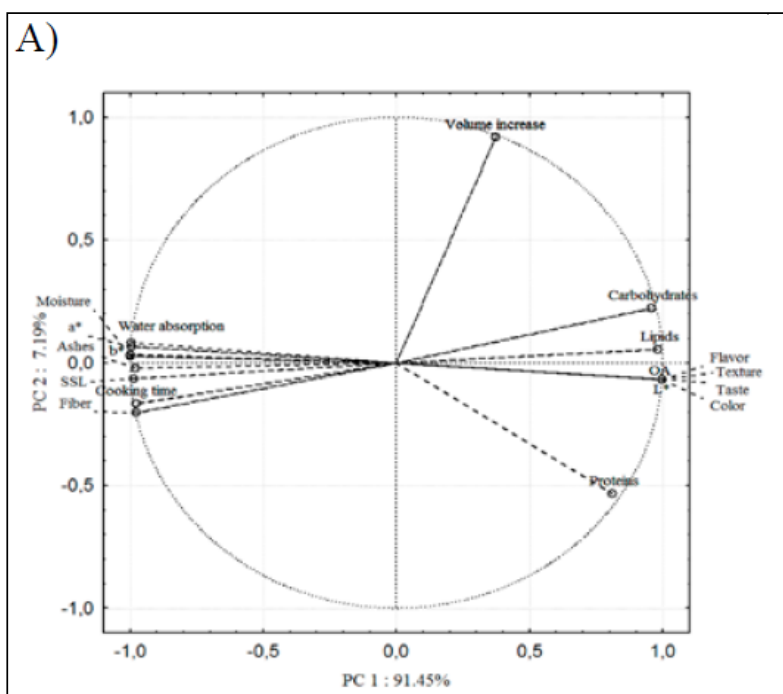

B)

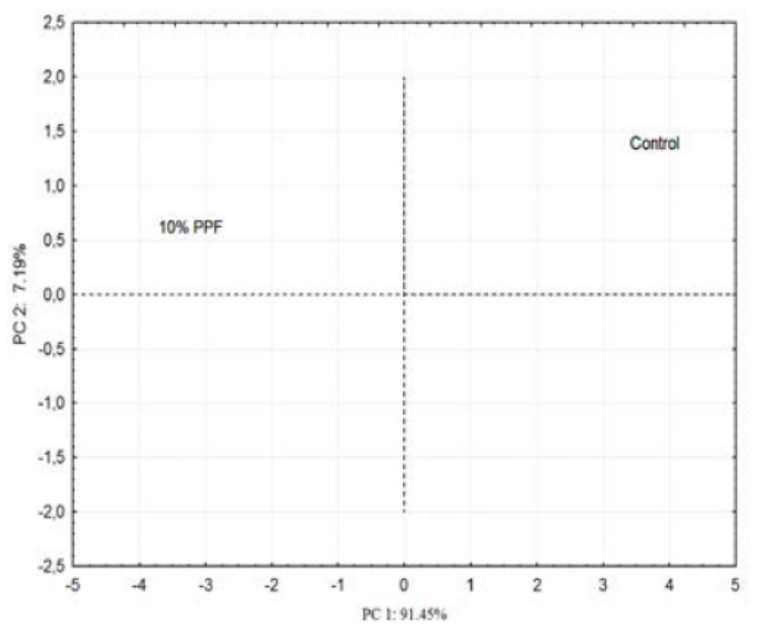

Figure 3 - Principal component analysis of the pasta formulations with better sensory results. (A). projections of the analyses and (B). projections of the formulations. Note: Control - without passion fruit peel flour; $10 \%$ PPF - formulation with $10 \%$ of passion fruit peel flour; SSL - soluble solids loss, OA - overall appearance.

with addition of maltodextrin, reported $\mathrm{PC} 1$ and PC2 were responsible for $49.07 \%$ and $17.07 \%$ of the variation observed, respectively. According to HAIR et al. (1998) values of PC variation ranging between 50 and $69 \%$ are acceptable, while values above $70 \%$ indicated that appropriate explanation of the variance should be among the first three components.

When the vectors are close to each other they indicated a positive correlation between the attributes; when they are at an orthogonal position it means there is possibly no linear correlation, and when they are at an $180^{\circ}$ angle it indicated a negative correlation (MONTANUCI et al., 2010). In the present study, all attributes evaluated in the sensory analysis (aroma, flavor, color, texture, and overall appearance), as well, as luminosity and contents of lipids and carbohydrates had positive correlations (Figure 3A). Such values were higher for the control formulation, as can be seen in figure 3B, due to its localization at right side of the graph. Conversely, the formulation containing $10 \%$ PPF was at the left side (Figure 3B); such also occurs to technological properties, chromaticity $\left(\mathrm{a}^{*}\right.$ and $\left.\mathrm{b}^{*}\right)$, moisture, fibers, and ashes contents (Figure $3 \mathrm{~A}$ ), and thus the values for these parameters were higher for the formulations with $10 \%$ PPF addition. Protein content and the volume increase had lower correlation with the different formulations, which can be due the similar values reported for these variables. Thus, the PCA demonstrated the correlation between the results obtained and their association with the formulations evaluated.

\section{CONCLUSION}

Regarding technological properties, the addition of PPF to gluten-free pasta increased cooking time, soluble solids loss and water absorption and modified color parameters in comparison to a control formulation with no PPF added. The control formulation and the formulation containing $10 \%$ had adequate acceptability indexes at values above $70 \%$. The $10 \%$ PPF addition to pasta increased fiber $(3.25 \%)$ and ashes $(2.15 \%)$ contents and lowered carbohydrates percentage (41.19\%) as well as energy value $(223.26 \mathrm{kcal} / 80 \mathrm{~g})$. Principal component analysis demonstrated the correlation between the evaluated attributes, and it allowed for discrimination of the formulations according to its characteristics. Therefore, passion fruit peel flour can be used as an alternative ingredient in order to increase the nutritional value of gluten-free pasta, the amount of $10 \%$ being recommended due to it leading to a more easily accepted formulation among testers.

\section{DECLARATION OF CONFLICTING INTERESTS}

The authors declare no conflict of interest.

Ciência Rural, v.48, n.12, 2018. 


\section{ACKNOWLEDGEMENTS}

The authors would like to thank the Department of Technology of the Universidade Estadual de Maringá (UEM).

\section{AUTHORS' CONTRIBUTIONS}

All authors contributed equally for the conception and writing of the manuscript. All authors critically revised the manuscript and approved of the final version.

\section{REFERENCES}

AACC International. Approved methods of analysis, 11th Ed. Method 66-50.01.Pasta and Noodle Cooking Quality - Firmness. Approved November 3, 1999. AACC International, St. Paul, MN, U.S.A. Available from: <http://dx.doi.org/10.1094/ AACCIntMethod-66-50.01>. Accessed: Sep. 23, 2018.

ABIMAPI - Associação Brasileira das Indústrias de Biscoitos, Massas Alimentícias e Pães \& Bolos Industrializados, Massas Alimentícias. Vendas (milhões tons), 2016. Available from: $<$ https://www.abimapi.com.br/>. Accessed: Mar. 18, 2017.

AJILA, C. M. et al Mango peel powder: A potential source of antioxidant and dietary fiber in macaroni preparations. Innovative Food Science and Emerging Technologies, v.11, p.219-224, 2010. Available from: <https://doi.org/10.1016/j.ifset.2009.10.004>. Accessed: Jun. 06, 2018. doi: 10.1016/j.ifset.2009.10.004.

AOAC - ASSOCIATION OF OFFICIAL ANALYTICAL CHEMISTS. Official methods Association of Official Analytical Chemists. Arlington: AOAC, (method 973.53), 16th ed., 1995.

ASMEDA, R. et al Relationships of damaged starch granules and particle size distribution with pasting and thermal profiles of milled MR263 rice flour. Food Chemistry, v. 191, p. 45-51, 2016. Available from: $<$ https://doi.org/10.1016/j. foodchem.2015.05.095>. Accessed: Jun 15, 2017. doi: 10.1016/j. foodchem.2015.05.095

BOUASLA, A. et al Gluten-free precooked rice pasta enriched with legumes flours: Physical properties, texture, sensory attributes and microstructure. LWT - Food Science and Technology, v.75, p.569-577, 2017. Available from: <https://doi.org/10.1016/j. lwt.2016.10.005>. Accessed: Mar. 18, 2018. doi: 10.1016/j. lwt.2016.10.005.

BRASIL. Agência Nacional de Vigilância Sanitária. Resolução $\mathrm{RDC}^{\circ}$ 54, de 12 de novembro de 2012. Dispõe sobre o Regulamento Técnico sobre Informação Nutricional Complementar. Diário Oficial da União, Poder Executivo, DF, Brasília, 2012.

BRASIL. Agência Nacional de Vigilância Sanitária. Resolução RDC n ${ }^{\circ}$ 93, de 31 de outubro de 2000. Dispõe sobre o Regulamento Técnico para Fixação de Identidade e Qualidade de Massa Alimentícia. Diário Oficial da União, Poder Executivo, DF, Brasília, 2000.

BRASIL. Agência Nacional de Vigilância Sanitária. Resolução RDC $\mathrm{n}^{\mathrm{o}} 263$, de 22 de setembro de 2005. Dispõe sobre o Regulamento Técnico para Produtos de Cereais, Amidos, Farinhas e Farelos. Diário Oficial da União, Poder Executivo, DF, Brasília, 2005.
BRASIL. Agência Nacional de Vigilância Sanitária. Resolução RDC $n^{\circ} 360$, de 23 de dezembro de 2003. Dispõe sobre o Regulamento Técnico sobre Rotulagem Nutricional de Alimentos Embalados, tornando obrigatória a rotulagem nutricional. Diário Oficial da União, Poder Executivo, DF, Brasília, 2003a.

BRASIL. Agência Nacional de Vigilância Sanitária. Resolução RDC $\mathrm{n}^{\circ} 359$, de 23 de dezembro de 2003. Dispõe sobre o Regulamento Técnico sobre Rotulagem Nutricional de Alimentos Embalados, tornando obrigatória a rotulagem nutricional. Diário Oficial da União, Poder Executivo, DF, Brasília, 2003b.

CORRÊA, R. C. G. et al The past decade findings related with nutritional composition, bioactive molecules and biotechnological applications of Passiflora spp. (passion fruit). Trends in Food Science \& Technology, v.58, p.79-95, 2016. Available from: $<$ http://dx.doi.org/10.1016/j.tifs.2016.10.006>. Accessed: Sep. 23, 2018. doi: 10.1016/j.tifs.2016.10.006.

COSTA, E. L. et al. Production and acceptance of a fresh tagliarini pasta fortified with passion fruit flour (Passiflora edulis Sims f. flavicarpa) and verification of its effect on the blood glucose levels. Nutrire, v.40, p.352-360, 2015. Available from: <http:// dx.doi.org/10.4322/2316-7874.71315>. Accessed: Sep. 22, 2018. doi: $10.4322 / 2316-7874.71315>$.

DHARMARAJ, U. et al. Preparation of semolina from foxtail millet (Setaria italica) and evaluation of its quality characteristics. Journal of Cereal Science, v.68, p.1-7, 2016. Available from: $<$ https://doi.org/10.1016/j.jcs.2015.11.003>. Accessed: Mar. 19, 2017. doi: $10.1016 /$ j.jcs.2015.11.003

DUTCOSKY, S. D. Análise sensorial de alimentos. (4 ${ }^{\text {th }}$ ed.). Curitiba: DA Champagnat, 2013.531p.

FERREIRA, S. M. R. et al. Utilization of sorghum, rice, corn flours with potato starch for the preparation of gluten-free pasta. Food Chemistry, v. 191, p.147-151, 2016. Available from: <https://doi. org/10.1016/j.foodchem.2015.04.085>. Accessed: Mar. 19, 2017. doi: 10.1016/j.foodchem.2015.04.085.

FOGAGNOLI, G.; SERAVALLI, E. A. G. Application of passion fruit peel powder in fresh pasta. Brazilian Journal of Food Technology, v.17, p. 204-202, 2014. Available from: <http:// dx.doi.org/10.1590/1981-6723.0614>. Accessed: Mar. 18, 2017. doi: $10.1590 / 1981-6723.0614$.

GATTA, B. et al. The role of hydration on the cooking quality of bran-enriched pasta. LWT - Food Science and Technology, v.84, p. 489-496, 2017. Available from: <https:// doi.org/10.1016/j.1wt.2017.06.013>. Accessed: Jan. 18, 2018. doi: 10.1016/j.lwt.2017.06.013.

HAIR, J. et al. Multivariate Data Analysis. ( $5^{\text {th }}$ ed) Upper Saddle River: Prentice-Hall, 1998.

HUMMEL, C. Macaroni Products: Manufacture, Processing and Packing. (2 ${ }^{\text {nd }}$ ed.) London: Food Trade, 1966, p. 287.

LIAO, H.; HUNG, C. C. Chemical composition and in vitro starch digestibility of green banana (cv. 'Giant Cavendish') flour and its derived autoclaved/debranched powder. LWT - Food Science and Technology, v. 64, p. 639-644, 2015. Available from: <https://doi. org/10.1016/j.lwt.2015.06.058>. Accessed: Mar. 18, 2017. doi: 10.1016/j.lwt.2015.06.058. 
LÓPEZ-VARGAS, J. H. et al Chemical, physico-chemical, technological, antibacterial and antioxidant properties of dietary fiber powder obtained from yellow passion fruit (Passiflora edulis var. flavicarpa) co-products. Food Research International, v. 51, p.756-763, 2013. Available from: <https://doi.org/10.1016/j. foodres.2013.01.055>. Accessed: Mar. 18, 2017. doi: 10.1016/j. foodres.2013.01.055

LORUSSO, A. et al. Use of fermented quinoa flour for pasta making and evaluation of the technological and nutritional features. LWT Food Science and Technology, v. 78, p. 215-221, 2017. Available from: < https://doi.org/10.1016/j.lwt.2016.12.046>. Accessed: May 25, 2017. doi: 10.1016/j.lwt.2016.12.046.

MANIWARA, $P$. et al The use of visible and near infrared spectroscopy for evaluating passion fruit postharvest quality. Journal of Food Engineering, v.143, p.33-43, 2014. Available from: <https://doi.org/10.1016/j.jfoodeng.2014.06.028>. Accessed: Sept. 24, 2018. doi: 10.1016/j.jfoodeng.2014.06.028.

MONTANUCI, F. D. et al. Caracterização sensorial e aceitação de Kefir adoçado integral e desnatado com inulina. Brazilian Journal of Food Technology, v. 14, p. 79-90, 2010. Available from: <https://doi.org/10.4260/BJFT201114E000110>. Accessed: May 20, 2017. doi: 10.4260/BJFT201114E000110.

MCGUIRE, R.G. 1992. Reporting of objective color measurements. Hort Science, v. 27, p. 1254-1255. Available from: $\quad<$ http://hortsci.ashspublications.org/content/27/12/1254. full.pdf.>. Accessed: Mar. 20, 2016.

MICELI, A. et al. The influence of addition of Borago officinalis with antibacterial activity on the sensory quality of fresh pasta. International Journal of Gastronomy and Food Science, v.2, p. 93-97, 2015. Available from: <http://dx.doi.org/10.1016/j.ijgfs.2014.12.004>. Accessed: Sept. 24, 2018. doi: 10.1016/j.ijgfs.2014.12.004.

MORENO, M. L. et al. Selective capture of most celiac immunogenic peptides from hydrolyzed gluten proteins. Food Chemistry, v. 205, p. 36-42, 2016. Available from: <https://doi. org/10.1016/j.foodchem.2016.02.066>. Accessed: Mar. 17, 2017. doi: 10.1016/j.foodchem.2016.02.066.

NUSS, E.T.; TANUMIHARDJO, S. A. Maize: a Paramount staple crop in the context of global nutrition. Comprehensive Reviews in Food Science and Food Safety, v. 9, p. 417-436, 2010. Available from: <https://doi.org/10.1111/j.1541-4337.2010.00117.x>. Accessed: Mar. 17, 2017. doi: 10.1111/j.1541-4337.2010.00117.x.

OLIVEIRA, C.F. et al. Extraction of pectin from passion fruit peel assisted by ultrasound. LWT - Food Science and Technology, v. 71, p. 110-115, 2016 a. Available from: <https://doi.org/10.1016/j.lwt.2016.03.027> Accessed: Mar. 17, 2017. doi: 10.1016/j.lwt.2016.03.027.

OLIVEIRA, C. F. et al. Evaluation of physicochemical, technological and morphological characteristics of powdered yellow passion fruit peel. International Food Research Journal, v. 23, p. 1653-1662, 2016b. Accessed: Sept. 23, 2018.
OVANDO-MARTINÉZ, M. et al. Unripe banana flour as an ingredient to increase the undigestible carbohydrates of pasta. Food Chemistry, v. 113, p.121-126, 2009. Available from: $<$ https://doi. org/10.1016/j.foodchem.2008.07.035>. Accessed: Mar. 17, 2017. doi: 10.1016/j.foodchem.2008.07.035.

PINHEIRO, E. R. et al. Optimization of extraction of high-ester pectin from passion fruit peel (Passiflora edulis flavicarpa) with citric acid by using response surface methodology. Bioresource Technology, v. 99, p. 5561-5566, 2008. Available from: <https:// doi.org/10.1016/j.biortech.2007.10.058>. Accessed: Mar. 17, 2017. doi: 10.1016/j.biortech.2007.10.058.

PHONGTHAI, S. et al. Effects of protein enrichment on the properties of rice flour based gluten-free pasta. LWT - Food Science and Technology, v. 80, p. 378-385, 2017. Available from: $<$ https://doi.org/10.1016/j.lwt.2017.02.044>. Accessed: Mar. 17, 2018. doi: 10.1016/j.lwt.2017.02.044.

REKAS, A.; LUKASIAK, K. M. A. Multivariate study of the correlation between addition of maltodextrin, MCG, HPMC and psyllium on the quality of instant fried noodles. LWT - Food Science and Technology, v. 62, p. 689-696, 2015. Available from: $<$ https://doi.org/10.1016/j.lwt.2014.12.027>. Accessed: Mar. 17, 2017. doi: 10.1016/j.lwt.2014.12.027.

SANGUINETTI, A. M. et al. Extending the shelf life of gluten-free fresh filled pasta by modified atmosphere packaging. LWT - Food Science and Technology, v. 71, p. 96-101, 2016. Available from: $<$ https://doi.org/10.1016/j.lwt.2016.03.010>. Accessed: Mar. 17, 2017. doi: 10.1016/j.lwt.2016.03.010.

SHARMA, G. M. et al. Gluten detection in foods available in the United States - A market survey. Food Chemistry, v. 169, p. 120-126, 2015. Available from: <https://doi.org/10.1016/j. foodchem.2014.07.134>. Accessed: Mar. 17, 2017. doi: 10.1016/j. foodchem.2014.07.134.

SOETAN, K. O. et al. The importance of mineral elements for humans, domestic animals and plants: A review. African Journal of Food Science, v. 4, p. 200-222, 2010. Available from: <https:// www.academicjournals.org/article/article1380713863_Soetan $\% 20$ et\%20al.pdf>. Accessed: Mar. 17, 2017.

SOLER, M. et al. Label-free SPR detection of gluten peptides in urine for non-invasive celiac disease follow-up. Biosensors and Bioelectronics, v. 79, p. 158-164, 2016. Available from: <https:// doi.org/10.1016/j.bios.2015.11.097>. Accessed: Mar. 17, 2017. doi: 10.1016/j.bios.2015.11.097.

TEIXEIRA, E. et al. Análise Sensorial de Alimentos. Florianópolis: Editora UFSC, 1987.

YING, L. M. Passion Fruit Infused Gluten Free Noodle: Optimization of Ingredient Levels Using Response Surface Methodology. Final Year Project, UTAR, 2016. Available from: $<$ https://pdfs.semanticscholar.org/e5a1/1 f05c34e2baca0fc5ef0d34 f12e0a0794f0d.pdf $>$. Accessed: Sep. 27, 2018. 